\title{
Computer Education Support Structures in Victorian Schools in the 1980s
}

\author{
Arthur Tatnall $^{1}$ and Bill Davey ${ }^{2}$ \\ ${ }^{1}$ Centre for International Corporate Governance Research, Victoria University, \\ Melbourne,Australia; Arthur.Tatnall@vu.edu.au \\ 2 School of Business Information Technology, RMIT University, Melbourne, Australia; \\ Bill.Davey@rmit.edu.au
}

\begin{abstract}
Prior to the 1970s, the idea of introducing school students to the use of computers, or of a school owing its own computer was difficult to imagine. This situation began to change during the 1970s and accelerated in the 1980s. While microcomputers were much cheaper and more easily handled than minis and mainframes, in the late 1970s they were still quite foreign to most school teachers. This paper tells the story of how a Travelling Computer Road Show, teachers seconded as Computer Education Consultants, a Computer Education Centre, Subject Teacher Associations and several other support structures were used in Victoria to facilitate the Microcomputers in Education revolution that changed the education landscape in the early to mid 1980s. The paper also reflects on how the adoption of computers in schools really affected school education.
\end{abstract}

Keywords: Computer education, Teacher/curriculum support structures, Curriculum consultant, Computer education centre, History

\section{Background - Schools in Victoria}

In Australia in the late 1970s and early 1980s the use of Computers in Education in Schools was becoming an important national consideration. The Commonwealth of Australia is a federation of six states and two territories each having a considerable degree of independence. Constitutionally, State Governments have responsibility for School Education, but in matters of perceived national importance, the Commonwealth Government adopts a policy position and supplies funding for specific education projects. Nevertheless, the State Government Education Ministries determine school curriculum, and how it is supported and delivered.

Whereas, previously the idea of a school owing its own computer seemed quite preposterous, the advent of the relatively inexpensive microcomputer in the 
late 1970s meant that schools could now afford to purchase one or more computer. Consequently, the use of computers in schools began to expand at a rapid rate. The tremendous and growing interest in the use of computers in education led the Commonwealth Government, in April 1973, to set up the Commonwealth Schools Commission National Advisory Committee on Computers in Schools (NACCS), whose purpose was to provide leadership and funding for Computer Education across all Australian states and territories. Another of its goals was co-ordination of Computer Education facilities and offerings in each of the States. NACCS published its first blueprint for Computer Education in Schools in October 1983 [1].

This paper will consider some of the education support structures introduced in the 1980s to facilitate the growing needs of schools for advice and assistance in developing and maintaining their programs for computers in education. Both of the paper's authors were Secondary School teachers in the 1970s and early 1980s, and between them were also involved in most of the support structures described. While also considering some Australia-wide issues, this paper will concentrate its perspective on the State of Victoria.

In the 1980s, the State of Victoria had several different types of schools. Firstly, there was the divide between Government and Non-Government Schools. As the name suggests, Government Schools were controlled directly by, and received their funding from the Victorian Ministry of Education. Their teachers were appointed, their conditions determined and their overall curriculum guidelines set by the Ministry. Non-Government schools were of two main types: Catholic Schools and Private Schools. In each case, these schools received no funding from the State, but did receive some funding and support from the Commonwealth Government. They employed their own teachers and determined their own curriculum within broad guidelines laid down by the Victorian Ministry of Education.

In the Government School sector, students up to the age of about twelve attended Primary Schools and then moved to either High (Secondary) Schools or Technical Schools. The idea of dividing students into two streams for their postprimary education was to allow that some students were more academically inclined, while others needed a more practical education. (In the late 1980s, these two Divisions were merged into what amounted to comprehensive post-primary schools.) Administratively, each of these school types was attached to a Division within the Ministry of Education. 


\section{The Beginnings of School Computing in Victoria}

School computing began in Victorian schools when a small number of mini computers started to appear in the early 1970 s $[2,3]$. This typically resulted from the exposure of particular teachers to computing during their university studies. In 1972, for example, Burwood High School in Melbourne was loaned a PDP-8 computer by Digital Equipment [4]. In 1973 McKinnon High School received a Government Innovations Grant to enable the purchase of an 8k Wang computer costing over $\$ 10,000$ (AUS) and requiring an annual maintenance contract of $15 \%$ of the purchase price. Because of this high maintenance cost Box Hill High School agreed to share the use (and costs) with McKinnon High School, each school having access to $4 \mathrm{k}$ memory. Box Hill used a Teletype terminal with a paper tape reader and accessed the computer via a dedicated telephone line, but this arrangement was soon seen to be unsatisfactory. These early computers were typically used by mathematics departments almost exclusively for the teaching of programming [4], so having very little overall impact on other aspects of education.

The biggest early impact on schools however, was introduction of the Monash Educational Computer System (MONECS). Before the advent of the PC, it was impossible for an average school to provide students with hands-on access to a computer. In 1974 a group at Monash University produced a system using marksense cards that allowed a class of 30 children to each get two runs in a one-hour period [5]. The MONECS system was used to teach programming in FORTRAN or BASIC. At this stage schools saw computing as a branch of mathematics concerned with algorithm design $[2,6]$.

Another development at this time was experimentation by the Victorian Technical Schools with use of Control Data's 'PLATO System' [7] of computerassisted instruction for the training of apprentices and for other possible applications. The system was, however, very expensive and not very useful or satisfactory in fulfilling its hope for educational purpose. Its use did not proceed. The arrival of the Apple II in 1977 saw the end of this period and the beginning of real advances in the use of computers in schools. At around $\$ 2000$ (AUS) for a $16 \mathrm{k}$ Apple II that used a tape drive (not supplied - you simply used your own cassette recorder) and a television (also not supplied) set as a monitor, the Apple II was affordable for schools.

It was not long before several different streams of computer education emerged in Victorian schools:

- Computers across the curriculum - computer use in different subject areas

- Computer Science

- Programming in mathematics

- Use of word processors by secretarial studies students 
- Logo

- Computer industry/business training in Technical Schools [2].

One of the early curriculum directions was 'computers across the curriculum' and AppleII software such as Lemonade, Hammurabi, and the First Fleet (convict) database showed the possibilities here. Acorn BBC computer software included a word processor, database manager and a role play simulation program called Suburban Fox (where students took the role of a fox and learned to survive). Several Teacher Subject Associations showed an early interest, particularly the Mathematics, Science and Commercial Teachers' Associations, and a new subject association: the Computer Education Group of Victoria (CEGV) was set up.

This was before the days of the ascendancy of the IBM PC and MS-DOS and schools made use of a variety of computers. The main ones were the Apple II, BBC (Acorn), Tandy TRS-80, Commodore 64, Microbee, (an Australian designed and built computer capable of running the $\mathrm{CP} / \mathrm{M}$ operating system), Micromation (also an Australian built $\mathrm{CP} / \mathrm{M}$ machine), IBM PC, and Macintosh. Other computers in use in schools included the Cromence, Sega, BBC Electron, Atari, Amiga, Sinclair ZX80 and several others.

There was little or no software compatibility between these early types of microcomputers and so it made a big difference to a school's computer education curriculum which computer they used. Like several other countries Australia even commenced a project to design an Australian Educational Computer [8], which fortunately (in retrospect) did not proceed past the design stage. One of the functions of the Victorian State Computer Education Centre (which we will discuss later) was to control the proliferation of these brands by supporting only a limited number on a 'recommended list'. This reduced the problem somewhat.

\section{Microcomputers in Schools - An Education Revolution?}

With today's mobile telephones that can send e-mail and take movies it is easy to forget the nature of the microcomputer revolution. The first microcomputer to catch the imagination of teachers and to appear in significant numbers in Victorian schools was the Apple II. In 1978, the early versions of this computer had $16 \mathrm{~Kb}$ of RAM and used a cassette tape recorder for loading software and a television set as a monitor. It is illustrative to look closely at the instructions that came with the demonstration tape to see what a person taking delivery of their first computer might need to deal with. Figure 1 shows a page from the booklet that came with the Apple II. 


\section{The Usual Procedure for Loading Tapes}

1. Make sure your computer is in Applesoft BASIC

2. Rewind the tape

3. Start the tape playing

4. Type LOAD

After you press RETURN the cursor will disappear. Nothing happens for from five to twenty seconds, and then the Apple beeps. This means that the tape's information has started to go into the computer. After some more time (depending on how much information is on the tape, but usually less than a few minutes) the Apple beeps again and the prompt character and the cursor reappear.

4a. If you got an error message such as ERR, the tape did not LOAD properly. Turn your computer off (with the switch in the back), and begin the process again at step one. NOTE: You cannot recover from a LOAD error by using RESET.

5. Stop the tape recorder and rewind the tape. The information has been transferred, and you are finished with the tape recorder for the time being.

Enjoy your new Apple!

Figure 1 Loading tapes [9]

Most of the personal computers of interest to schools (Apple II, Tandy TRS80, Commodore 64, and Atari) loaded their software from cassette tape and most adopted the Texas Instruments standard of 300 baud. The Apple, however, used a faster 1200 baud when loading from cassette. The Computer Education Road Show (described later) and most Computer Education Consultants from 1978 to 1980 used tape loading to demonstrate software. The knowledgeable consultant would leave the tape sound output on so that they would be able to hear when it was loading properly and when a restart was needed.

In 1979 the first disk drives appeared and a Word Processor program could be obtained from Apple. The instruction booklet advised (Figure 2 below), all in friendly CAPS, as most printers did not have lower case:

RUNNING UP THE SYSTEM

AFTER SWITCH ON AND AFTER INSERTING THE WORD PROCESSOR DISK IN

THE DISK DRIVE, TYPE ' 6 '; THEN HOLD DOWN THE 'CTRL' KEY WHILE

PRESSING ' $\mathrm{P}$ '; THEN PRESS 'RETURN'.

WHEN THE DISK HAS STOPPED RUNNING THE SCREEN WILL DISPLAY AN INTRODUCTORY MESSAGE. TO CONTINUE WITH THE PROGRAM PRESS ANY KEY.

Figure 2 Word Processor disk instructions [10] 
Once this 'simple' procedure was undertaken the instructions assure the user that almost nothing could go wrong with the program. That is, unless they had done something silly like pressing the Reset Key or typing in "too many lines" (see Figure 3).

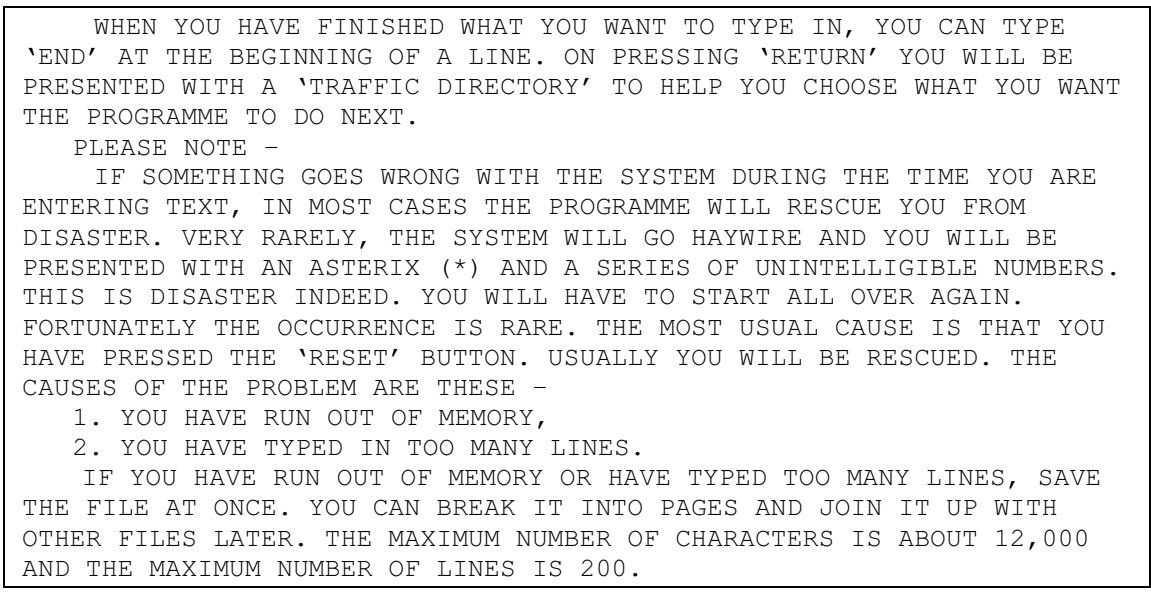

Figure 3 Word Processor instructions [10]

These examples show that the first microcomputers, while more simple to operate than their predecessor minis and mainframes, were certainly not consumer or teacher ready. The next factor in this scenario was staff training. It is difficult for universities to train teachers in technology that has not yet been invented. Many Mathematics and Science teachers under the age of about thirty at the time had been given some computer training in the university with punch card machines using COBOL or Fortran (normally in a situation of a one or two day turnaround for each program). However, a teacher older than this would probably have attended a University or Teachers College without available computing facilities. The situation in schools was one of enormous excitement created by the promise of the new computers that were almost affordable, could be used for programming and had amazing on-screen graphics that fired the imagination. At the same time these computers were very unstable, had been put together by people who saw CTRL 6P as a logical way of starting a disk drive and had miniscule memory size, capable only of simple things like storing and handling the number of characters that could be contained in five pages of a book. The Victorian Education Ministry could see the future for computers and the need to have students learning about them, but a lack of human resources familiar with computers must have looked like a giant hurdle. The education system had responded to the need for science equipment in the 1960s with large equipment grants, but then it had science-trained teachers to implement this program and to 
make good used of the new equipment. In computing, the equipment deficit was just as large, but supplying teachers able to use it would not be a simple task. Support was urgently needed.

\section{Early Attempts to Offer Support to Schools}

The introduction of the personal computer in the late 1970s produced unprecedented growth in the use of computers in schools in Victoria during the 1980s. This situation was also reflected in other Australian states as well as in many other countries. The growth of use of computers, however, existed in the absence of enough trained teachers and without national or international models of the educational use of computers in schools beyond simple programming. In Victoria, a number of different approaches were used in an attempt to provide support to schools. In the early 1980s, most innovative developments were from individual teachers or small groups of teachers, and a systematic approach was not put in place until the mid 1980s.

Document analysis and interviews of the main protagonists at the time has identified a number of different models used in Victoria to address the need for computer education support for schools. These models included:

- The spontaneous formation of self-help groups amongst teachers.

- Use of existing professional teacher associations (- Mathematics, Science and Commercial Teachers Associations).

- Formation of the Computer Education Group of Victoria (CEGV) to raise and discuss issues.

- Creation of a Higher School Certificate (Year 12) level Computer Science subject.

- Use of special purpose computer education conferences.

- A locally produced computer education journal.

- Vendor-directed support for schools using specific types of computer hardware.

- An Education Department sponsored 'travelling computer education road show'.

- Regionally-based computer education consultants provided by the Education Department.

- Creation of the Victorian State Computer Education Centre (SCEC) - a centralised support unit.

- A seeding program centred on specific types of teachers.

- At later stages, equipment grants and government-funded computer education demonstration schools.

A good deal of documentary evidence is still available to study these models. This includes policy statements, copies of journals from the period, conference proceedings and minutes of meetings as indications of intention, with curriculum 
statements and enrolment numbers as measures of success. To supplement these findings we conducted interviews with instigators and directors of each model. Interviewees included senior officers of SCEC, a traditional teacher organization, the originator of one of the largest spontaneous teacher groups, a writer of one of the innovative programs used in the curriculum, a past president of the CEGV, a conference chair from the subject specific conferences, a member of the government policy group, an examination panel chair from the Higher School Certificate (HSC) subject and people involved in the various types of seeding programs.

The study of these models over the ten years from 1980 to 1990 has shown that each contributed to the advance of computer use in schools, but that none was entirely successful in achieving all its stated aims. Details of these support models, and reasons for their success or failure, are discussed in this paper. The history of computers in schools is not one of hardware and software alone. This study has shown that the efforts of a wide variety of champions were needed to reach into the education community. The lessons of this history are obviously applicable today.

\subsection{The Computer Travelling Road Show}

In 1978-1979, the Computer Policy Subcommittee of the Victorian Education Ministry Director Generals' Policy Committee produced a plan for the introduction of computers to schools. A key feature of the plan was that: "There is an immediate need for post-primary divisions to appoint full-time/part-time regional consultants for 1980 to establish clearing houses and assist in school program development and to co-ordinate the development of appropriate skills within each region" [11]. The plan arose from talks between Bainbridge (one of the Regional Directors of Education) and a group of Inspectors of schools. As a result the Secondary Mathematics Committee set up a 'Computer Education' Subcommittee [12] in recognition of the potential of computers in mathematics education (and possibly also in other aspects of education).

This subcommittee then set up a Computer Travelling Road Show that in 1979 commenced visits to schools around the State to promote the use of computers in mathematics education as well as in other subject areas. Members of the group would travel in twos or threes, normally bringing a 16k Apple II with tape drive (on loan from Computerland in Sydney) to demonstrate computer applications involving graphics, mathematics, commerce and word processing (rather than just programming) to teachers at curriculum days and staff meetings. This represented the Education Department's first official recognition of the importance of computers in education $[4,12]$. 
Interestingly, although teachers of Mathematics were the prime movers in these early days, they did not remain a significant force in this area into the later 1980s. What appears to have happened is that mathematics teachers, many having had some experience with computers at university, were quick to use their computers (typically the Apple II) in teaching programming, but then had difficulty in identifying other suitable mathematical applications. In many cases these teachers then moved over to the teaching of computing: Computer Awareness and Computer Science, and gave up any attempt to use computers in mathematics. Today, mathematics would be one of the subject areas making least use of computers.

Growth of interest in using computers in schools exploded at this time and at a regional computer conference in June 1979, twenty-five schools were represented. Of these only two had school computers (an Apple and a Cromenco), three used computers owned by a teacher, four were making use of a computer at a local tertiary institution and the rest were "interested in learning what was possible".

\subsection{The Director General's Computer Policy Sub-Committee}

During the period 1978-1980, the discretionary fund of the Director of Secondary Education was used to support microcomputer purchase in a limited number of schools. The Director General's Computer Policy Sub-Committee also commissioned Anne McDougall, from Melbourne University Education Faculty, to undertake a study of the potential uses of computers in Victorian schools [2, 3]. The report's recommendations [13] included a major commitment to in-service education of teachers, and that adequate numbers of Computer Education Consultants should be made available. The main recommendations were:

- Schools should be encouraged and assisted to offer Computer Awareness education for all students.

- In schools where it was desired that computer programming be taught, the establishment of Computer Science courses was preferred to the inclusion of programming in Mathematics courses.

- A major commitment should be made to the in-service education of teachers for Computer Awareness and Computer Science.

- Adequate numbers of Computer Education Consultants should be made available.

- Secondment should be arranged for some skilled teachers to work in Central or Regional Centres on the preparation of courseware.

- Standardisation of equipment and computer programming languages was recommended, to facilitate the exchange of courseware, transferability of teacher skills and for equipment maintenance.

- A large pool of courseware programs should be developed for use in a wide variety of subject areas. Central or Regional Centres should be established 
for the preparation, modification, documentation and cataloguing of educational programs. These should be staffed mainly by seconded teachers.

- It was also recommended that a resource library for computer education materials should be established [13: 31].

The Computer Policy Sub-Committee agreed in the need to separate Computer Education from mathematics, and influenced the formation of three (divisional) Computer Education Curriculum Committees [3]. It also approved the appointment of three Computer Education Consultants with state-wide responsibilities. These (one year tenure) secondments were to commence in February 1980.

The Victorian Education Department at this time had three very separate (and often non-cooperating) divisions (Primary, Secondary, and Technical Divisions), each of which pursued its own policies and directions. This was evidenced in the Computer Education area particularly in the friction, often apparent, between the Secondary and the Technical Divisions. These divisions had radically different ideas on policy; that of the Technical Schools Division being towards industry standard equipment and training for employment, while the main concern of the Secondary Schools Division was (after the recommendations of the McDougall report) for Computer Awareness. This important distinction in policy was partly due to the historical differences between the two divisions, the Secondary Division having (traditionally) considered its role as in both provision of a general education to all students, and in preparation of some students for tertiary studies; while the Technical Division had always been primarily concerned with preparation of students for apprenticeships, and training students for employment. It is thus not surprising that the Technical Division should have stressed computer industry compatibility as important in education. The problem remained until 1983 when the divisions were finally abolished.

\subsection{The Secondary Computer Education Committee}

In 1980 the Secondary Computer Education Committee was formed [14] with a membership made up from members of the Board of Inspectors of Secondary Schools, seconded computer education consultants and practicing Secondary School teachers, including some from the Secondary Mathematics committee [15]. The Committee's brief was the production of Computer Awareness course guidelines, investigation of Computer Science as a discipline, publication of computer education articles, collection and propagation of 'public domain' software and provision of in-service education [14]. In 1980 a 'Software Library' was set up using available public domain software suitable for Apple II and CP/M computers [14]. 
During 1981 the Secondary Computer Education Committee, the Technical Division Computer Education Committee and the newly formed Primary Committee for Computers in Education all functioned to produce curriculum guidelines and newsletters, and to conduct in-service education for teachers. The Secondary Division appointed several teachers as part-time Regional Computer Education Consultants. Also at this time, 'Ardoch Computer Centre' was set up in metropolitan Melbourne by the Computer Policy Sub-Committee as a state-wide resource, and in a rare example of co-operation, a software library was set up as a joint venture of the Secondary and Technical Divisions. The mission of the software library was to sift through the available public domain software for Apple and $\mathrm{CP} / \mathrm{M}$ and to distribute to schools that which was found to be suitable.

An important evolution in thinking about computer education occurred at about this time, in the realisation that computer hardware was not all important. Before this, long periods were spent by teachers in discussing the relative merits of Apple versus Tandy, and Commodore versus CP/M computers. The focus now began to move away from the hardware to the importance of software, systems, and applications.

\subsection{Computer Awareness Courses}

In developed countries around the world today secondary school students are quite aware of the benefits of information technology and of the many and varied uses of computers. In Victoria, secondary school students now know a good deal about the Internet and broadband, play computer games, make extensive use of computer software and take photos using their mobile phones. This was, however, certainly not the case in the late 1970s and early 1980s when the first PCs began to make their appearance in Australian schools [16]. In 1983 Moursund [17] suggested that the idea that there was a need for the general student population to become computer literate began in the U.S. in the late 1960s, leading to the development of a number of courses and individual units in the early 1970s. Morsund described these early courses as being in Computer Awareness rather than Computer Literacy, in that they aimed only to give students a level of understanding that would enable them to talk sensibly about computers, and involved little or no experience of actually working with computers.

Computer Awareness courses in Australia, however, began to appear in the late 1970s and early 1980s when the first microcomputers started to be seen in schools. Unlike the situation described by Moursund, however, distinctions between Computer Awareness and Computer Literacy were not made in Australia, and Victorian Computer Awareness courses were always much more practical and involved a good deal of computer use rather than being almost wholly theoretical. 
In Victoria, the Secondary Computer Education Committee put an early priority on the introduction of Computer Awareness in the middle secondary school years. In a 1980 curriculum document [15] the Committee noted that although computers had become indispensable in the operations of science, business and government, they did not currently play a significant role in Victorian secondary education [16]. To justify the introduction of computers and related technology into the secondary school curriculum the Committee argued that as computers were beginning to exercise an important and growing influence on society, that part of the school curriculum concerned with preparation for living in society should contain at least some elements of computer education [15]. The Committee's Year 10 curriculum guidelines noted that: “... we define Computer Education in terms of computer 'awareness' - the possession of skills and knowledge to enable informed judgments to be made on the basis of what is seen or heard about computers." [15:1]. It added that "... the future citizen, ignorant of computers, will be functionally disadvantaged in a computer oriented society. In terms of 'social obligation' therefore, a strong case can be made for Computer Education. Since computers have significant social, political and economic consequences, an awareness of these consequences is essential to informed decision-making and to the democratic process." $[15: 1]$.

The guidelines proposed for a Year 10 Computer Awareness subject strongly stressed the interdisciplinary nature of this subject matter and that Computer Awareness should not be equated with Computer Programming. The document specified the following content $[15: 4-14]$ :

- What is a computer and how does it work?

- Computer use and programming

- Computer Applications and Implications

The introduction of courses like this, however, both created a need for teacher professional development and acted to make many teachers themselves aware of the possibilities of using a computer for other aspects of education. These courses were a phenomenon of the 1980s and vanished after this, their task having been fulfilled.

\subsection{Subject Associations and User Groups}

The Computer Education Group of Victoria (CEGV) was formed in the late 1970s as an association of academics, computer salespeople, teachers, and other interested in the use of computers in education. It came into prominence in 1979 when it launched the first Computer Education Conference in Australia. The CEGV, and its counterparts in other states, exerted a considerable influence on computer education through professional development activities, annual conferences, journals and the provision of other publications and resources. 
In September 1982, the authors, along with a secondary school principal, formed the Apple users group: VACE (Victorian Apple Computers in Education). From small beginnings VACE grew to have a membership in excess of 200 schools [12]. Unlike the CEGV, VACE was very much a 'grass roots' organisation involving mainly practicing teachers. VACE conducted about two meetings per school term and fulfilled an in-service function. It had its own services section and software library and the VACE charter listed aims covering in-service education, helping with hardware problems and opportunities, software swapping, providing libraries of books and software and bulk buying schemes. The organisation was furiously busy for about 5 years then became irrelevant as the number of teachers with self-sufficient skills reached critical mass. Although the Apple II was by far the most common computer used in secondary schools, the TRS-80, Acorn BBC computer, locally made Microbe and various 'industrial' computers used by Technical Schools were common enough to also need their own user groups. Many of these groups then delivered hours of useful in-service training and technical support.

\section{Regional Computer Education Consultants}

An important school curriculum support mechanism used by the Victorian Ministry of Education in the late 1970s and 1980s was the Regional Subject Consultant. This was a time of decentralisation and the Ministry had set up twelve Regional Offices around the state, and in Melbourne, where many administrative matters were dealt with at a local level. The regions were not in any way really independent, but were used as a means of localising policies and decisions made by the Ministry of Education. An important function of the Regional Offices was to act as a base for the Regional Subject Consultants who spent much of their time serving the curriculum needs of local schools.

The Consultants were practicing schoolteachers who were seconded from their schools, usually on a part-time basis, to work from the Regional Education Office. They were chosen for their subject expertise, teaching ability, willingness to adapt to and lead educational change, and ability to get on with and work with other teachers. They were subject specialists (in the case of secondary schools) and were appointed only for a period of twelve months at a time. The idea was that although they could be re-appointed for following years, they should not become permanent advisors who might then lose contact with the school classroom. Having to spend half of their time doing their normal teaching job in a school meant that there was little chance that they could forget what it was like to be a classroom teacher. In the curriculum consultancy part of their job, however, they rarely had any 
interaction with school students, working instead with teachers and school principals.

As some Commonwealth Government money went into funding the Regional Subject Consultants, although they themselves were Government School teachers, their brief extended to servicing both Government and Non-Government schools. The first three statewide Computer Education Consultants were appointed in 1980, with additional appointments following in 1981. Unlike most other consultants, Computer Education Consultants were pioneering a new area of education and had little in the way of established precedent, techniques, or materials to assist them. A common starting point for teachers in thinking out how to best present subject matter to their students is to remember how they themselves were taught. As the use of computers in education was an entirely new area, few teachers had any experience with this, and so had little idea of where to begin. Their task was thus to introduce, and offer suggestions on the use of computers in schools. This work had various different forms including:

- Professional Development activities run at the Regional Office and open to teachers from any school - often based around use of a particular software product, an example being use of the 'First Fleet Database' in history classes.

- Professional Development activities within a given school. Although this could be similar to the activities described above, more typically they involved discussion of how some aspects of computing could be taught, or how computers could be usefully employed in various subject areas.

- Demonstration of educational computer software, and discussion of how it could be used in the classroom.

- Configuration and other work with computer hardware.

- Consultations with individual teachers on curriculum related matters.

- Individual consultations with school principals.

Computer software available at that time depended on which microcomputer was being used. In the early 1980s the Apple II was the most common computer in Primary and Secondary Schools. There were also significant numbers of Commodore 64, Tandy TRS-80, Cromenco (CP/M) and Atari computers in use. Typically, those teachers involved in the early days came with a science or mathematics background.

With its main goal being to prepare students for the workforce, the Technical Schools Division saw a need to use only 'industry standard' equipment in all its teaching. The main use seen for computers was in the commerce area and as the Apple II did not use the $\mathrm{CP} / \mathrm{M}$ operating system or the $\mathrm{S} 100$ bus, and run WordStar and dBASE software (thought by the Technical Division to be the standard at this time) it was not considered to be an 'industry standard' computer. Hence, it was not considered suitable for use in Technical Schools. Recommended instead was a $\mathrm{CP} / \mathrm{M}$ computer called the Micromation. 
The promise of personal computers in the early 1980s was just that; a promise. It could take several tries for an experienced hobbyist to load software from a tape drive and the first PCs were far from consumer items with well-developed interfaces and manuals. Some of the most useful programs were those written by teachers. As mentioned earlier, the Apple II Word Processor manual was presented entirely in CAPS. This meant that the Regional Computer Consultant was part repairman, part programmer, part innovation champion, but mostly visionary with just enough knowledge to help the growing tide of interested teachers. The amazing thing about this system of consultants was the success rate. By 1985 the majority of secondary schools, and many primary schools, had embraced personal computers to the extent of having a class lab, often supplied by funds raised largely at the local level.

\section{The State Computer Education Centre (SCEC)}

In Victoria, the early development of Computer Education in schools was 'bottom up', beginning with the efforts of a small number of teachers. It took some time for the Education Department itself to become sufficiently interested to set up any form of central involvement. When the Computer Education 'explosion' began in 1983 and the Victorian Education Department saw the need for some form of 'top down' planning and control, it became clear that there was a need for some central focus for computer education in the state. Formation of the State Computer Education Centre (SCEC) was the eventual result.

In January 1984, the State Computer Education Centre (SCEC) was set up in temporary premises at the old Moorabbin High School with 10 seconded staff, along with twelve regional computer education centres staffed by seconded teachers. In 1985, all positions were advertised and staffing at SCEC was formalised with the centre headed by the Senior Computer Education Officer, with a Software Co-ordinator, Professional Development Co-ordinator, Curriculum Co-ordinator, Educational Computer Systems Analyst, and Equal Opportunity Officer (Non-Government) holding Deputy Principal Positions. Seventeen Senior Teacher positions (five at SCEC and twelve in the regions), and four Assistant Teacher positions made up a total staff of twenty-seven professional officers [3].

SCEC played a significant role in setting the direction of educational computing in Victoria for the next three years. It developed policy, produced curriculum documents, evaluated and distributed educational software, evaluated computer hardware and produced the 'recommended list' of computer systems for use in schools, facilitated interstate contacts and the sharing of resources, conducted professional development activities, and generally co-ordinated computer education in the state. 


\subsection{The Notion of Central Operations}

Stated policies of devolution and school-based decision making not-withstanding, in the early 1980s the Education Department of Victoria still retained a strong central administration. There were several key aspects of the computer education situation in Victoria that distinguished it from other curriculum areas and that pointed towards the perceived need for a central operation. The first of these was the smallness of the number of people with expertise in the area; when a human resource is limited it is a common response of any controlling group to centralise it, and this is what happened in the case of computer education. Secondly, in every state it was policy to recommend specific computer hardware for use in schools. This was necessary in order to comply with Government tender, offset and preferred supplier requirements. Government offset policy was designed to encourage local manufacture of computing equipment by requiring that 'foreign' companies re-invest, in the state, $30 \%$ of the profits they made as the result of being nominated as a 'preferred supplier'. The process of evaluating computing systems and recommending that preferred supplier status be conferred on a particular company was a task that needed to be done centrally. It would not have been economically possible for such a function to be regionalised, let alone left to individual schools, and so it was a task performed by all State Computer Education Centres. This task alone could be used as a justification by Governments for setting up these Centres.

After the Computer Education money began to flow, all states also need to determine how Commonwealth and State grant money in computer education would be allocated to schools. Giving advice in this area was also a function made easier by the existence of some form of State Computer Education Centre or central committee. In this, computer education is not unique and a similar situation would have applied to any curriculum area having a large number of dollars to dispense. Not too many other curriculum areas have, however, recently been in this position. Co-ordination of in-service education and the professional development of teachers was another function that was perceived as sensibly done from the centre, as was the co-ordination of the production of curriculum materials. Dispensing of services could however easily have been decentralised more than it was. The reasons this did not happen have been largely historical and become apparent after studying the history of the SCEC [12].

In a quite short period of time in the early to mid 1980s every Australian state moved to set up (or extend) some form of State Centre for Computer Education, becoming the source of advice for central policies and the vehicle, at least to some degree, for central control. Thus, the notion of a State Computer Education Centre as a curriculum arm of the central administration became accepted across Australia. 


\subsection{State Centres for Computer Education in Other Australian States}

The state centres for computer education in Australia were primarily a phenomenon of the 1980s with few established before, and few surviving long past that time. Most of the services provided by these centres, while important to the new area of Computer Education at the time were, in most cases, later able to be provided in different ways on a more decentralised basis. Judgements on the success, or otherwise, of the centres is difficult to make without much more data than was ever collected, but the little we have suggests that they filled an important role without which the adoption of computers by schools would have been much more haphazard. It is also an interesting reflection on these centres that few of the professional teachers who staffed them in the 1980s remained long in school education into the $1990 \mathrm{~s}$, but that is another story. This paper provides a brief overview of the formation and role of Computer Education Centres in the various states and territories of Australia during the 1980s.

South Australia, Tasmania and (to an extent) Western Australia) commenced programs of Computer Education (mainly of computer programming) earlier than the other states, and the role of the central operation in these states was partly determined by a need to maintain a central computer and to use it to provide a service to schools. This was not the case in the other states [14].

\subsubsection{South Australia}

South Australia first became involved in Computer Education with the setting up of the Angle Park Computing Centre in 1968 [14]. The South Australian Education Department had a long-standing policy on 'School Computing Activities', which in part stated that:

- Computing is an object of study in its own right

- Computing provides the means of enhancing and extending traditional components of the school curriculum.

- Computing and related technology have the potential to change the curriculum, the manner in which that curriculum is implemented and to improve the general organisational procedures used by schools [18:46].

To implement its policies, the South Australian Education Department established the 'Schools Computing Section' which comprised professional staff, support staff and regional advisers, and maintained the Computing Centre.

\subsubsection{Tasmania}

Tasmania also had an early involvement with educational computing, beginning with the introduction of a year 12 Computer Studies course in 1972. Tasmania 
developed a statewide timesharing network for educational purposes (TASNET) and, in the mid-1970s, set up the Elizabeth Computer Centre (ECC). The role of the ECC involved: “... development of educational and administrative software for the network and for microcomputers; the provision of expert advice on computing to the Department, to schools and to colleges; the provision of advice and training to Tasmanian teachers and the production of the regular newsletters ..." [18:49].

\subsubsection{Western Australia}

Western Australia also involved itself with computer education before microcomputers were common. Policy on the educational use of computers in Western Australia, developed by the Schools Computing Branch, was published in 1980/1981. "The Schools Computing Branch has six full-time professional staff and five technical staff. These officers provide schools with advice on hardware, software and pedagogic matters and carry out all the other functions associated with the activities supported by the Schools Computing Centre." [1:11].

\subsubsection{Tasawa}

In 1981 the states of Tasmania, South Australia and Western Australia began to co-operate in computer education. This co-operation was enabled by their common use of Acorn BBC computers. In frustration at what they perceived as a lack on interest from the other states, they set up the TASAWA consortium to facilitate this co-operation by sharing development of software and curriculum materials for computer education.

\subsubsection{Queensland}

Moving in a quite different direction to the TASAWA states, Queensland schools showed a preference for the Apple II, and Queensland made no move to set up a Computer Education Centre or to produce curriculum software. Arguably, Queensland's most significant contribution to the field was the development, during the mid 1980s, of a Year 12 Information Processing syllabus using fourthgeneration database-query languages and conceptual schema. Most other Computer Science courses were concerned with the study of computer architecture, algorithms, and programming in third-generation languages like Pascal and BASIC. Queensland's course started a trend in a quite new direction.

\subsubsection{New South Wales}

Along with Victoria, the Education Department of New South Wales was a little slow in formally sponsoring of use of computers in schools [14]. The creation of a 
'Computer Education Unit' in 1983 was described as follows: "This will provide a critical mass of expertise, combining complementary skills, and a visible focus for computer education activities and innovation to support work in schools and regions. It will bring together work on curriculum development; the evaluation, development and distribution of software and other resource materials, consultancy support and in-service education of teachers; and advice on the selection of computer equipment for schools. This will help avoid unnecessary duplication of effort and provide a much more effective basis for support to schools throughout the State, both secondary and primary." [19:115].

\section{Computing as a Study in its Own Right - Higher School Certificate Computer Science}

In 1981, mainly because of many years of effort by a group of academics, Computer Science was first offered as a Higher School Certificate (HSC) subject in Victoria. Personnel from the Education Department had little involvement in creating or in determining the nature and content of this subject.

The content of this subject included the following areas: computer structure and data representation, algorithms and modelling, programming languages, data structures, input/output devices, file structures, system software, and social implications [20]. In addition, students undertook one of the following two optional units: computers in science and engineering, or computers in business and government. Practical work was seen as an important part of the course.

Of relevance to this paper, however, is the affect that this subject had on computing support structures. While some would have argued at the time that the existence of this subject drew resources away from other aspects of computers in education, we hold the opposite view. The argument that this group of university education faculty academics and some teachers put forward against teaching about computers in this way was that teaching programming meant setting up computer laboratories in schools and so concentrating all the computers in one place. They argued that the computers would then not be accessible to teachers of history, geography, English, and other similar subjects. They also argued that teaching Computer Science would tend to attract the boys and not the girls. We, on the other hand along with a good number of others, would argue that teaching Computer Science generated a need in schools for the purchase of a large number of computers that would otherwise have been difficult to justify. No doubt there were some instances where the teacher of Computer Science managed to exclude others from the computer laboratory, but in our experience of schools at the time (both authors were Computer Science examiners), this was very unusual. 
The introduction of Computer Science also meant that a number of teachers now had a good reason to learn much more about computers, and not just programming, so becoming a useful resource to other teachers in the school. It was all very well for the opponents of this view to stress the needs of other teachers as an argument against Computer Science, but it is not clear where they thought these other teachers would get the support they so much needed if it was not from other teachers within the school - there were not enough Computer Education Consultants to provide this support at the level required, and this was something that the Computer Science teachers could assist with. Fortunately the problem did not last long as larger numbers of teachers became sufficiently computer literate, and the number of computers in schools increased significantly.

\section{Conclusion}

The first microcomputer used in schools in Victoria was installed around 1978. By 1985 a Year 12 Computer Science subject was in place and almost every High school in the state had at least one computer laboratory. This change in less than ten years is amazing, and reflects a climate of intense enthusiasm and vision for the microcomputer, and of the success of attempts to support and train teachers in a completely new area. Factors in this success were the Travelling Computer Road Show, the State Computer Education Centre and in particular, the Computer Education Consultant. These Consultants were taken from the classroom because of their expertise and enthusiasm so they could help their colleagues in full knowledge of the working conditions in schools. The people they helped as they came from the same background also extended them trust. The measure of their success is the speed with which they did away with the need for their services.

In the mid 1980s, several Regional Offices experimented with the concept of a General Curriculum Consultant, rather than subject Consultants. These teachers were typically seconded full-time and were chosen for their broad view of the school curriculum. They would still do some subject consultancy work, but would also work on other more general curriculum tasks. The early 1990s saw the end of the seconded Regional Consultant, when the State Government changed its funding model to give money previously spent on consultants directly to schools to spend on professional development in any way they chose. This meant that most of this work fell to either educational consultants working independently on a commercial basis and Education Faculty academics, neither group having much contact or experience with the school classroom. The State Computer Education Centre and most of the Regional Computer Centres also closed at this time and development of educational computer software by the Ministry of Education ceased. 
Those of us involved at the beginning of the Computer Education revolution in Australia had great hopes that the introduction of computers would make a profound difference and significantly improve the quality of school education. Now that over 25 years has passed, when one looks back and asks if this has happened, the answer would have to be equivocal. School students are now very well aware of the computer, how it is used and its place in business and society. They now take computers completely for granted, as they do with other items of technology. They have very little idea of computer history or realise that we did not always use computers. Most Secondary School students now complete their assignments in Microsoft Word, and students frequently send each other e-mails and look for information on Google or in Wikipedia. However, the question of whether education has undergone some sort of fundamental change due to the introduction of the computer is still debatable.

\section{References}

1. Commonwealth Schools Commission, Teaching, Learning and Computers. Report of the National Advisory Committee on Computers in Schools. 1983, Commonwealth Schools Commission: Canberra.

2. Tatnall, A. and B. Davey, Streams in the History of Computer Education in Australia, in History of Computing in Education, J. Impagliazzo and J.A.N. Lee, Editors. 2004, Kluwer Academic Publishers / IFIP: Assinippi Park, Massachusetts. p. 83-90.

3. Tatnall, A., The Growth of Educational Computing in Australia, in History, Context, and Qualitative Methods in the Study of Education, I. Goodson, F. and M.J. Mangan, Editors. 1992, University of Western Ontario, Canada.: London, Ontario. p. 207-248.

4. Salvas, A.D., Personal communication. 1985: Melbourne.

5. Monash Computing Museum. MONECS Deamon Educational Computer system. [Web] 2003 [cited 2004 Feb 2004]; Available from: http://www.csse.monash.edu.au/museum/.

6. Tatnall, A., Curriculum Cycles in the History of Information Systems in Australia. 2006, Melbourne: Heidelberg Press.

7. Plato Learning. History of Plato Learning. 2004 [cited 2004 Feb 2004]; Available from: http://www.plato.com/aboutus/company_history.asp.

8. Tatnall, A., Designing the Australian Educational Computer. Education, 1990. 110(4): p. 453-456.

9. Apple Computer Inc., The Apple Tapes Introductory Programs for the Apple II plus. 1979, Cupertino, California: Apple Computer Inc.

10. Apple Computer Inc., Instruction booklet to accompany word processing disk. 1979, Cupertino, California: Apple Computer Inc.

11. Bainbridge, W.J., Internal memo to all policy committees. 1979, Ministry of Education, Victoria: Melbourne.

12. Tatnall, A., The Role of the State Computer Education Centre of Victoria, in MA (preliminary) thesis, Education, Editor. 1985, Deakin University: Geelong.

13. McDougall, A., Computers and Post-Primary Education in Victoria: a Study of Needs. 1980, Education Department of Victoria, Computer Policy Committee: Melbourne.

14. Tatnall, A. The Formation and Role of State Centres of Computer Education in Australia in the 1980s. in $8^{\text {th }}$ IFIP World Conference on Computers in Education (WCCE-2005). 2005. Stellenbosch, South Africa: IFIP. 
15. Secondary Computer Education Committee, Year 10 Computer Education: Guidelines for Secondary Schools. 1980, Education Department of Victoria: Melbourne.

16. Tatnall, A. and B. Davey, Early Computer Awareness Courses in Australian Secondary Schools: Curricula from the late 1970s and early 1980s, in History of Computing and Education 2, J. Impagliazzo, Editor. 2006, Springer: New York. p. 107-116.

17. Moursund, D., Precollege Computer Literacy: a Personal Computing Approach. $2^{\text {nd }}$ edition. 1983, Eugene, Oregon: International Council for Computers in Education.

18. Shears, L.W. and E.C. Dale, Computers in Education. A report to The Honourable Robert Fordham M.P. Minister of Education, Victoria. 1983, Ministry of Education: Melbourne.

19. Smith, B.W. Computer Education in New South Wales Government Schools. in Could you use a computer? The 1983 Australian Computer Education Conference. 1983. Melbourne: CEGV.

20. Victorian Institute for Secondary Education, Handbook for 1985 Year 12 Curriculum and Assessment. 1984, Melbourne: Victorian Institute for Secondary Education. 